\title{
Estimation of Optimum Period of Time between Scheduled Maintenance in Iraqi Oil Refineries by using Operation Research Techniques
}

\author{
Ali Moosa Taqi ${ }^{1}$, Sedqi Esmaeel Rezouki ${ }^{2}$ \\ ${ }^{1,}$ Baghdad University, Collage of Engineering, Al- Jadrriya Compound, Road, Baghdad, Iraq
}

\begin{abstract}
Operations research is a powerful mathematical method available to managers to solve their administrative problems. Some methods of operational research can be applied in field of maintenance management, in other words, applying scientific methods to finding solutions to industrial problems, including maintenance work. The objective of this study to use the probability model to estimate the optimum period of scheduled preventive maintenance to give the manager the opportunity to choose the best maintenance time with the lowest cost. Microsoft Excel was used to build a special probability model to solve this problem and perform calculations. The probabilistic model to solve this problem was carried out in Najaf Oil Refinery (NOR) as a case study instead of other Iraqi oil refineries. The three production units were used in NOR for this purpose.
\end{abstract}

Keywords: Preventive maintenance, Corrective maintenance,Scheduled maintenance, Lost Production Cost

\section{Introduction}

Industry began to develop largely and fast, and mechanization began to apply all fields. Complicated and high-cost machinery and equipment appeared, particularly in the field of oil facilities. Therefore, the need urged to develop maintenance systems to maintain the machines and equipment for as long as possible. Also, maintenance is no longer limited to a group of engineering and technical events carried out by specialists in these fields, but also became an administrative and accounting effort to plan, organize, direct and control. However, despite the importance of the maintenance management of oil refineries and the economic and social importance they represent to people's lives, studies and research in the maintenance of refineries are still limited, at least in Iraq.

This study will discuss a detailed explanation of the systems developed by the Researchers for the purpose of use in the maintenance of Iraq's oil refineries management such as cost and time for maintenance work by estimating the optimum time for scheduled preventive maintenance in Iraqi oil refineries by Najaf Oil Refinery as a case study through the equipment of the three production units in the refinery case study.

\section{Maintenance definition and types}

Maintenance is usually defined as its combination of all technical and administrative actions, including supervisory actions, intended to retain an item in, or restore it to, a state in which it can perform a required function [1].

There are many classifications for maintenance in books, papers and various studies. One of these ranking which is classified maintenance into two main types which one of these types is named preventive and two is named corrective as shown below in Fig. 1

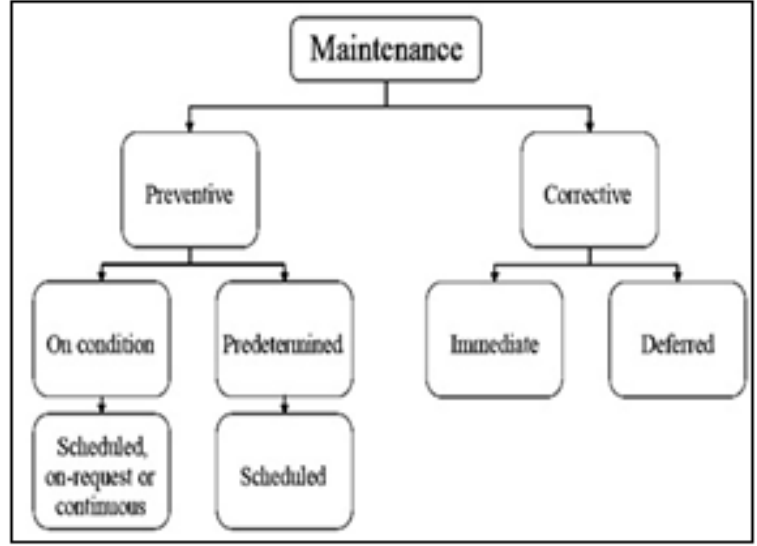

Figure 1: Types of maintenance [2]

\subsection{Preventive Maintenance}

Preventive maintenance is defined as maintenance carried out at predetermined intervals or according to prescribed criteria and intended to reduce the probability of failure or the degradation of the functioning of the equipment. Preventive maintenance can be predetermined or condition based:

2.1.1 Predetermined maintenance: Preventive maintenance carried out in accordance with established intervals of time or number of units of use (i.e. scheduled maintenance) but without previous item condition investigation;

\subsubsection{Condition based maintenance:}

Preventive maintenance based on performance and/or parameter monitoring and the subsequent actions [2].

\subsection{Corrective Maintenance}

Corrective maintenance also called breakdown maintenance, is the oldest strategy in the industry [3] is maintenance carried out after fault recognition and intended to put the equipment into a state in which it can perform a required function. Corrective maintenance can be immediate or 
International Journal of Science and Research (IJSR)

ISSN (Online): 2319-7064

Index Copernicus Value (2015): 78.96 | Impact Factor (2015): 6.391

deferred:

2.2.1 Immediate maintenance: Maintenance which is carried out without delay after a fault has been detected to avoid unacceptable consequences;

2.2.2 Deferred maintenance: Corrective maintenance which is not immediately carried out after fault detection but is delayed according to given maintenance rules[2].

\section{Importance of maintenance management}

1) To ensure continuity in production.

2) To ensure efficiency in production.

3) To ensure productivity.

4) To deliver goods on the right time.

5) To ensure good housekeeping [4].

\section{Introduction to Iraqi Oil Refineries}

The refining industry in Iraq began very early, when Haditha Oil refinery was established in 1949 followed by Dora refinery in 1953. The process continued to grow and flourish in certain eras and decline in others, depending on political and economic factors such as wars, embargoes and so on.

The nineteen state petrol refineries are distributed in all governorates of Iraq and are administratively administered by three public companies affiliated to the Federal Oil Ministry, these are [Researchers]:

a) North Refineries Company: The largest oil company affiliated to the Ministry of Oil. It is capable of refining (410000) barrels per day and is associated with the refineries (North, Saladin, Kirkuk, al-Kisk, Saynia, and Qayara.

b) Midland Refineries Company: one of the most important oil companies affiliated to the Federal Oil Ministry. It is capable of refining (220000) barrels per day. It is associated with Dora, Najaf, Samawah, Diwaniyah and Karbala refineries.

c) South Refineries Company: one of the largest oil companies affiliated to the Federal Oil Ministry, established in 1969. It is capable of refining (270000) barrels per day. The company consists of three refineries, Basra; Dhiqar and Maysan.

The following table (Table 1) lists the names of the government refineries in Iraq, their affiliation, their establishment dates, their production capacities, and their status of work after the invasion of ISIL(Islamic Stateof Iraq and the Levant) to several provinces on 10/6/2014 and the destruction, burning, and sabotaging of vital facilities, most importantly oil refineries [Researchers].

Table 1: Iraqi Oil Refineries [Researchers]

\begin{tabular}{|c|c|c|c|c|c|}
\hline No & Location & Dependency & $\begin{array}{c}\text { Comm. } \\
\text { Date }\end{array}$ & Capacity & $\begin{array}{c}\text { production } \\
\text { stance }\end{array}$ \\
\hline 1 & $\begin{array}{l}\text { North Oil } \\
\text { Refinery }\end{array}$ & $\begin{array}{c}\text { North Refineries } \\
\text { Company }\end{array}$ & 1983 & $\begin{array}{c}170000 \\
\text { BPD }\end{array}$ & Stopped \\
\hline 2 & $\begin{array}{l}\text { Salahuldin } 1 \\
\text { Oil Refinery }\end{array}$ & $\begin{array}{c}\text { North Refineries } \\
\text { Company }\end{array}$ & 1982 & $\begin{array}{l}70000 \\
\text { BPD }\end{array}$ & Stopped \\
\hline 3 & $\begin{array}{l}\text { Salahuldin } 2 \\
\text { Oil Refinery }\end{array}$ & $\begin{array}{c}\text { North Refineries } \\
\text { Company }\end{array}$ & 1984 & $\begin{array}{l}70000 \\
\text { BPD }\end{array}$ & Stopped \\
\hline 4 & $\begin{array}{l}\text { Lube Oil } \\
\text { Refinery } \\
\end{array}$ & $\begin{array}{c}\text { North Refineries } \\
\text { Company }\end{array}$ & & $\begin{array}{c}250000 \\
\text { TPY }\end{array}$ & Stopped \\
\hline
\end{tabular}

\begin{tabular}{|c|c|c|c|c|c|}
\hline 5 & $\begin{array}{l}\text { Kirkuk Oil } \\
\text { Refinery }\end{array}$ & $\begin{array}{l}\text { North Refineries } \\
\text { Company }\end{array}$ & 1973 & $\begin{array}{c}30000 \\
\text { BPD }\end{array}$ & Unstopped \\
\hline 6 & $\begin{array}{c}\text { Kasek Oil } \\
\text { Refinery }\end{array}$ & $\begin{array}{c}\text { North Refineries } \\
\text { Company }\end{array}$ & 1982 & $\begin{array}{l}10000 \\
\text { BPD }\end{array}$ & Stopped \\
\hline 7 & $\begin{array}{l}\text { Seneyah Oil } \\
\text { Refinery }\end{array}$ & $\begin{array}{c}\text { North Refineries } \\
\text { Company }\end{array}$ & 1978 & $\begin{array}{c}30000 \\
\text { BPD }\end{array}$ & Stopped \\
\hline 8 & $\begin{array}{l}\text { Qayyarah Oil } \\
\text { Refinery }\end{array}$ & $\begin{array}{c}\text { North Refineries } \\
\text { Company }\end{array}$ & 1956 & $\begin{array}{c}14000 \\
\text { BPD }\end{array}$ & Stopped \\
\hline 9 & $\begin{array}{l}\text { Hadetha Oil } \\
\text { Refinery }\end{array}$ & $\begin{array}{l}\text { North Refineries } \\
\text { Company }\end{array}$ & 1949 & $\begin{array}{l}16000 \\
\text { BPD }\end{array}$ & Unstopped \\
\hline 10 & $\begin{array}{l}\text { Durra Oil } \\
\text { Refinery }\end{array}$ & $\begin{array}{c}\text { Midland Refineries } \\
\text { Company }\end{array}$ & 1955 & $\begin{array}{c}140000 \\
\text { BPD }\end{array}$ & Unstopped \\
\hline 11 & $\begin{array}{l}\text { Lube Oil } \\
\text { Refinery }\end{array}$ & $\begin{array}{c}\text { Midland Refineries } \\
\text { Company }\end{array}$ & - & $\begin{array}{c}120000 \\
\text { TPY }\end{array}$ & Unstopped \\
\hline 12 & $\begin{array}{l}\text { Najaf Oil } \\
\text { Refinery } \\
\end{array}$ & $\begin{array}{c}\text { Midland Refineries } \\
\text { Company }\end{array}$ & 2006 & $\begin{array}{c}30000 \\
\text { BPD }\end{array}$ & Unstopped \\
\hline 13 & $\begin{array}{c}\text { Samawah Oil } \\
\text { Refinery }\end{array}$ & $\begin{array}{c}\text { Midland Refineries } \\
\text { Company }\end{array}$ & 1978 & $\begin{array}{c}30000 \\
\text { BPD }\end{array}$ & Unstopped \\
\hline 14 & $\begin{array}{l}\text { Diwaniya Oil } \\
\text { Refinery }\end{array}$ & $\begin{array}{c}\text { Midland Refineries } \\
\text { Company }\end{array}$ & 2008 & $\begin{array}{c}20000 \\
\text { BPD }\end{array}$ & Unstopped \\
\hline 15 & $\begin{array}{l}\text { Karbala Oil } \\
\text { Refinery }\end{array}$ & $\begin{array}{l}\text { Midland Refineries } \\
\text { Company }\end{array}$ & $\begin{array}{c}\text { Under } \\
\text { constru- } \\
\text { ction }\end{array}$ & $\begin{array}{l}140000 \\
\text { BPD }\end{array}$ & - \\
\hline 16 & $\begin{array}{l}\text { Basra Oil } \\
\text { Refinery }\end{array}$ & $\begin{array}{c}\begin{array}{c}\text { South Refineries } \\
\text { Company }\end{array} \\
\end{array}$ & 1974 & $\begin{array}{l}210000 \\
\text { BPD }\end{array}$ & Unstopped \\
\hline 17 & $\begin{array}{l}\text { Lube Oil } \\
\text { Refinery }\end{array}$ & $\begin{array}{c}\text { South Refineries } \\
\text { Company }\end{array}$ & 1996 & $\begin{array}{c}100000 \\
\text { TPY }\end{array}$ & Unstopped \\
\hline 18 & $\begin{array}{l}\text { Thiqar Oil } \\
\text { Refinery }\end{array}$ & $\begin{array}{c}\text { South Refineries } \\
\text { Company }\end{array}$ & 1981 & $\begin{array}{c}30000 \\
\text { BPD }\end{array}$ & Unstopped \\
\hline 19 & $\begin{array}{l}\text { Missan Oil } \\
\text { Refinery }\end{array}$ & $\begin{array}{c}\text { South Refineries } \\
\text { Company }\end{array}$ & 2000 & $\begin{array}{l}30000 \\
\text { BPD }\end{array}$ & Unstopped \\
\hline
\end{tabular}

\section{Introduction to the Case Study}

Najaf oil refinery (NOR), affiliated to the external refineries commission of the Central Refineries Company, is a medium capacity refinery with a production capacity of 30,000 barrels per day in three units in a capacity of (10000) barrels per day for each unit. Each single unit produces a range of $(20-22 \%)$ of naphtha, (14\%) of kerosene, $(22 \%)$ of gasoil, and $(51 \%)$ of diesel.

The foundation stone of NOR was laid on 3/10/2003 after identifying the suitable land with an area of (326) acres. The actual operation of NOR started by installing the first productive unit of the refinery on $10 / 2 / 2006$ to witness on $7 / 10$, the opening of NOR with a production capacity of (10000) barrels per day. After about (17) months, exactly on $15 / 3 / 2008$, the second unit was opened with the same specifications of the first refining unit in terms of production capacity as (20000) barrels per day. The Central Refineries Company continued working hard to have the refinery reach in its designing capacity to (30000) barrels per day by setting up the third refinery unit, opened on 15/8/2009. In addition to the construction of refining units, a large number of tanks with fixed and mobile ceilings and different sizes and capacities have been constructed to increase the capacity of the reservoir. This will give it greater flexibility in the production process and emergency situations. Twenty two reservoirs and a storage card of 87 million liters were implemented as well as the new reservoir of Najaf of 125 million liters, bringing the total capacity of the reservoir up to (212) million liters, and this capacity of the reservoir provides the capability to increase the capacity of the refinery.NOR employs a very large number of engineers, technicians, administrators and others. The number of permanent staff is (798), 400 of whom are Najaf residents, 198 are Babylonians, 200 are Karbala residents, (221) 


\section{International Journal of Science and Research (IJSR) \\ ISSN (Online): 2319-7064}

Index Copernicus Value (2015): 78.96 | Impact Factor (2015): 6.391

engineers, (414) technicians, and (163) administrators \& guards in addition to (24) other workers are temporary employees [Researchers].

\section{Statistical Method Assessing Scheduled Preventive Maintenance Cycle}

The use of operational research methods to estimate the appropriate standard times for carrying out preventive maintenance at the lowest possible cost requires some information on the three production units, the time of preventive maintenance, the lost production cost, and the equipmentmaintenance cost.

The Researchers will estimate the best time for preventive maintenance on the three production units at Najaf oil refinery through knowledge of preventive maintenance costs and the cost of stopping production due to maintenance work in the refinery case study.

\subsection{Scheduled Preventive Maintenance Cost}

There are two basic types of main resources required to carry out maintenance work in general they are [8]:-

a) Human Resources (Manpower)

a) Materials and spare parts

The cost of preventive maintenance in the refinery case study is often composed of the cost of materials and spare parts used in preventive maintenance in addition to the cost of the manpower in the maintenance of engineers and technicians because all the equipment used in the refinery under study belong to the maintenance department in the refinery.

The Researchers prepared a rate of scheduled preventive maintenance costs by visiting the maintenance department's sections in the refinery and surveying the cost of the scheduled maintenance of each section and the costs of human resources (manpower) as well as the cost of materials and spare parts used in the process of scheduled preventive maintenance (SPM).
Prior to this, it was necessary for the Researchers to calculate the mean time to repair production units in Najaf OilRefinery for the cost of staff working in scheduled maintenance. The duration of the scheduled maintenance of the equipment and machines of the entire production unit ranged from (20-30) days. The Researchers calculated the mean time to repair of preventive maintenance based on the preventive maintenance period in the refinery under study during the years (20122016) for the three production units which turned to be (26.344) days as follows:-

$$
\begin{aligned}
& \text { Mean of PM time of each production unit } \\
& =\frac{28.5+26.375+27.562+22.7+26.583}{5} \\
& =26.344 \ldots \ldots \ldots \ldots \ldots \text { (1) }
\end{aligned}
$$

The Researchers also considered this period for the purpose of calculating the cost of staffs working in the maintenance during the scheduled preventive maintenance in the refinery, considering that the average amount paid to the engineer in the refinery annually is 17400000 Iraqi Dinars and the average of what the technician receives in the refinery annually is 15202800 Iraqi Dinars as follows-:

Cost of maintenance engineers during PM

$$
\begin{aligned}
& =\frac{\text { cost of engineers staff }}{26.344} \\
& =\frac{17400000}{365} \ldots \ldots \ldots \ldots \ldots
\end{aligned}
$$

Cost of maintenance technicians during PM

$$
\begin{aligned}
& =\frac{\text { cost of tecnichal staff }}{26.344} \\
& =\frac{15202800}{365} \ldots \ldots \ldots \ldots \ldots
\end{aligned}
$$

Therefore, it is possible now to calculate the cost of scheduled preventive maintenance in Najaf Oil Refinery clearly through the table (2) which is equal to $183,845,550.28$ ID as shown below:

Table 2: Preventive maintenance cost in Najaf Oil Refinery [Researchers]

\begin{tabular}{|l|c|c|c|c|}
\hline Cost of S.P.M. & \multirow{2}{*}{$\begin{array}{c}\text { Average cost } \\
\text { of materials } \\
\text { Departments } \\
\text { of maintenance }\end{array}$} & $\begin{array}{c}\text { cost of engineers staff (ID) } \\
\text { (ID) }\end{array}$ & $\begin{array}{c}\text { cost of technical staff (ID) } \\
\text { (N*average cost of every } \\
\text { technical laborer) }\end{array}$ & $\begin{array}{c}\text { Total Preventive } \\
\text { maintenance cost of } \\
\text { department (ID) }\end{array}$ \\
\hline Heavy equipment & 4100000 & $6 * 1,255,580.96=7533485.76$ & $19 * 1,097,267.3=20848078.7$ & $32,481,564.46$ \\
\hline Valves & 4235000 & $7 * 1,255,580.96=8789066.72$ & $4 * 1,097,267.3=4389069.2$ & $17,413,135.92$ \\
\hline Pipes and welding & 8875750 & $13 * 1,255,580.96=16322552.48$ & $35 * 1,097,267.3=38404355.5$ & $63,602,657.9$ \\
\hline Electricity & 1290000 & $4 * 1,255,580.96=5022323.84$ & $8 * 1,097,267.3=8778138.4$ & $15,090,462$ \\
\hline Pumps & 2603500 & $7 * 1,255,580.96=8789066.72$ & $10 * 1,097,267.3=10972673$ & $22,365,240$ \\
\hline \multicolumn{7}{|l|}{ Small machines } & 100000 & $20 * 1,255,580.96=25111619.2$ & $7 * 1,097,267.3=7680871.1$ & $32,892,490$ \\
\hline \multicolumn{7}{|l|}{ Total Scheduled Preventive maintenance cost for maintenance departments in Najaf Oil Refinery (ID) } & $\mathbf{1 8 3 , 8 4 5 , 5 5 0 . 2 8}$ \\
\hline
\end{tabular}

\section{2 lost production cost because of P.M. stopping}

The cost of maintenance stoppage can be calculated by the following equation:
Lost production cost

$$
\begin{aligned}
& =\text { Production capacity } \\
& * \text { Downtime period } \\
& * \text { Average price ......... }
\end{aligned}
$$

To solve this equation, its variables must be calculated: 


\section{International Journal of Science and Research (IJSR) \\ ISSN (Online): 2319-7064}

Index Copernicus Value (2015): 78.96 | Impact Factor (2015): 6.391

\subsubsection{Production capacity}

The Researchers visited the production department in the refinery to calculate the production capacity for each type of oil derivatives (naphtha, kerosene, gasoil and diesel) as well as the quantity of crude oil received during the five years of study (2012-2016). As shown in the following table.

Table 3: Production capacity in NOR for (2012-2016)[Researchers]

\begin{tabular}{|c|c|c|c|c|c|}
\hline $\begin{array}{l}\text { Productions } \\
\left(\mathbf{M}^{3}\right)\end{array}$ & $\mathbf{2 0 1 2}$ & $\mathbf{2 0 1 3}$ & $\mathbf{2 0 1 4}$ & $\mathbf{2 0 1 5}$ & $\mathbf{2 0 1 6}$ \\
\hline Naphtha & 182376 & 220370 & 216334.696 & 214462.17 & 248025.736 \\
\hline Kerosene & 100767.5 & 102768.9044 & 92707.446 & 100453.884 & 103928.336 \\
\hline Gasoil & 173308.949 & 220414.8 & 218506.312 & 199250.763 & 198540.497 \\
\hline Diesel & 618204 & 754288 & 724478 & 686419.54 & 864016.748 \\
\hline Crude oil & 1111169.449 & 1328765.204 & 1282908.954 & 1228266.357 & 1449569.317 \\
\hline
\end{tabular}

\subsubsection{Downtime Period}

To calculate the number of stoppage hours in the three production units for the five years of study (2012-2016) in Najaf Refinery, the Researchers visited the Production Department in the refinery to calculate the number of annual downtime due to scheduled preventive maintenance work as shown in the following table.

Table 4: Downtime period neither in NOR for (20122016)[Researchers]

\begin{tabular}{|l|c|c|c|c|}
\hline \multirow{2}{*}{$\begin{array}{l}\text { S.P.M. } \\
\text { Year }\end{array}$} & \multicolumn{3}{|c|}{ Preventive Maintenance } & \multirow{2}{*}{$\begin{array}{c}\text { Total } \\
\text { (Hr.) }\end{array}$} \\
\cline { 2 - 4 } & Unit One & Unit Two & Unit Three & 1317 \\
\hline 2012 & 0 & 684 & 633 & 661.5 \\
\hline 2013 & 661.5 & 0 & 0 & 260.5 \\
\hline 2014 & 0 & 0 & 260.5 & 0.83 \\
\hline 2015 & 1057 & 544.83 & 0 & 1601.83 \\
\hline 2016 & 0 & 0 & 0 & 0 \\
\hline \multicolumn{6}{|l}{ Total stoppage hours in the three production units } & 3840.83 \\
\hline
\end{tabular}

\subsubsection{Average Price}

To complete the variables of equation (4) the prices of oil derivatives produced in Najaf refinery must be calculated and at the selling price of diesel to the Ministry of Electricity - the Al-Haidariyah power station, which is provided with at least 2,400 cubic meters per day as well as the oil pipeline company - the Oil Terminal of Najaf to Distribution of petroleum products in addition to the price of purchase of crude oil as shown in the following table.

Table 5: Average Price of NOR's Production for (20122016)[Researchers]

\begin{tabular}{|c|c|}
\hline Petroleum products & Price (ID) \\
\hline Naphtha (ID/M $\left.{ }^{3}\right)$ & 42000 \\
\hline Kerosene (ID/M $\left.{ }^{3}\right)$ & 125000 \\
\hline Gasoil (ID/M $\left.{ }^{3}\right)$ & 125000 \\
\hline Diesel (ID/M ${ }^{3}$ ) & 60000 \\
\hline Crude oil (ID/Br) & 5850 \\
\hline
\end{tabular}

Now that all equation (4) variables have been found, the cost of stoppage due to preventive maintenance can be found by table (6) which equals (2104800677 ID/year) as shown below.

Table 6: Lost production cost of NOR for (2012-2016)[Researchers]

\begin{tabular}{|c|c|c|c|c|c|c|c|c|c|c|c|c|c|c|c|c|c|c|c|c|}
\hline \multirow[b]{2}{*}{$\begin{array}{l}\text { Petroleum } \\
\text { products }\end{array}$} & \multicolumn{4}{|c|}{2012} & \multicolumn{4}{|c|}{2013} & \multicolumn{4}{|c|}{2014} & \multicolumn{4}{|c|}{2015} & \multicolumn{4}{|c|}{2016} \\
\hline & 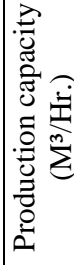 & 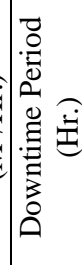 & 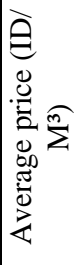 & 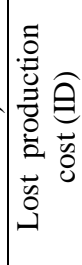 & 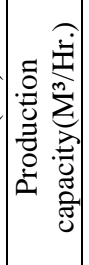 & 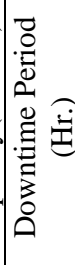 & 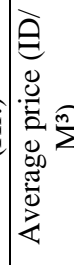 & 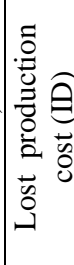 & 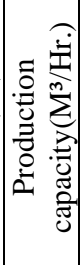 & 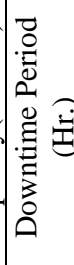 & 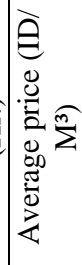 & 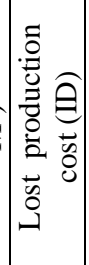 & 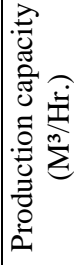 & 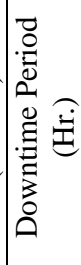 & 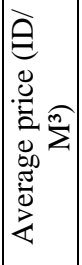 & 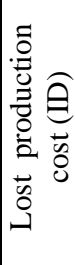 & 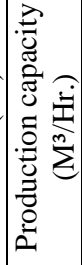 & 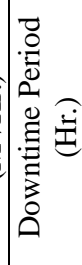 & 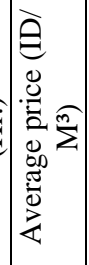 & 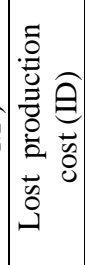 \\
\hline Naphtha & $\begin{array}{l}\hat{\jmath} \\
\text { D. } \\
\text {. }\end{array}$ & $\underline{m}$ & 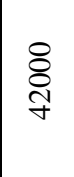 & \begin{tabular}{l} 
ర్ \\
$\infty$ \\
$\stackrel{D}{+}$ \\
\multirow{J}{\infty}{} \\
$\stackrel{+}{+}$
\end{tabular} & $\begin{array}{l}\& \\
\varnothing \\
\infty \\
\ddot{d}\end{array}$ & $\frac{n}{\square}$ & 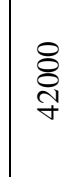 & 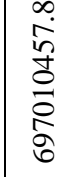 & $\begin{array}{l}\text { ते } \\
\text { ర్ర } \\
\dot{d}\end{array}$ & 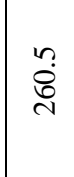 & 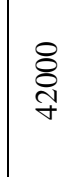 & 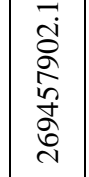 & $\begin{array}{l}\text { Oे } \\
\stackrel{n}{7} \\
\stackrel{+}{+} \\
\text {. }\end{array}$ & 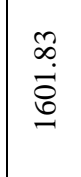 & \begin{tabular}{l}
$\stackrel{\sim}{\Im}$ \\
\multirow{\sigma}{*}{}
\end{tabular} & 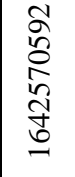 & 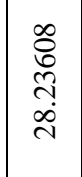 & 0 & $\begin{array}{l}\stackrel{ి}{0} \\
\text { f }\end{array}$ & 0 \\
\hline Kerosene & 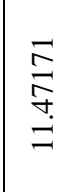 & $\underline{\underline{m}}$ & 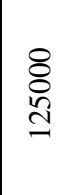 & $\begin{array}{l}\hat{2} \\
\hat{\delta} \\
\text { ñ } \\
\infty \\
\infty \\
\infty\end{array}$ & $\begin{array}{l}\text { लुे } \\
\stackrel{n}{\rightarrow} \\
\vec{n}\end{array}$ & $\frac{n}{8}$ & 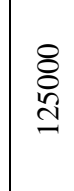 & 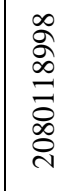 & 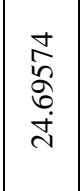 & 每 & \begin{tabular}{l}
8 \\
8 \\
0 \\
\hdashline
\end{tabular} & 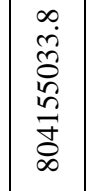 & $\begin{array}{l}\stackrel{\infty}{\infty} \\
\stackrel{\infty}{\infty} \\
\stackrel{\sim}{+}\end{array}$ & $\begin{array}{l}\tilde{\infty} \\
\stackrel{\infty}{0} \\
\stackrel{0}{0}\end{array}$ & 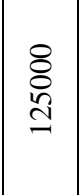 & 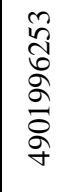 & $\begin{array}{l}\frac{J}{d} \\
\frac{d}{m} \\
\infty \\
i\end{array}$ & 0 & 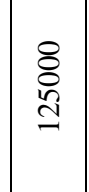 & 0 \\
\hline
\end{tabular}




\section{International Journal of Science and Research (IJSR) \\ ISSN (Online): 2319-7064}

Index Copernicus Value (2015): 78.96 | Impact Factor (2015): 6.391

\begin{tabular}{|c|c|c|c|c|c|c|c|c|c|c|c|c|c|c|c|c|c|c|c|c|}
\hline Gasoil & 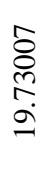 & $\underline{\vec{g}}$ & 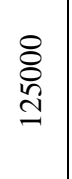 & 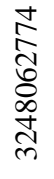 & $\begin{array}{l}\vec{b} \\
\stackrel{n}{=} \\
=\end{array}$ & $\frac{n}{8}$ & $\begin{array}{l}8 \\
8 \\
\\
\end{array}$ & 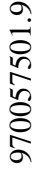 & 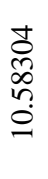 & 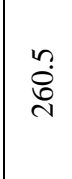 & 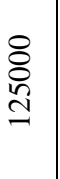 & $\begin{array}{l}\stackrel{+}{d} \\
\text { o } \\
\text { o } \\
\text { 寺 }\end{array}$ & $\begin{array}{l}\stackrel{0}{\stackrel{*}{f}} \\
\stackrel{\underbrace{}}{=}\end{array}$ & $\begin{array}{l}\infty \\
\stackrel{0}{0} \\
\stackrel{0}{0}\end{array}$ & 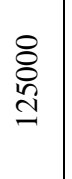 & 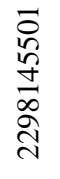 & $\begin{array}{l}\text { ஜे } \\
\text { రి } \\
\infty \\
= \\
=\end{array}$ & 0 & $\begin{array}{l}8 \\
8 \\
\\
\end{array}$ & 0 \\
\hline Diesel & 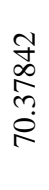 & $\frac{\sigma}{2}$ & $\begin{array}{l}8 \\
8 \\
8\end{array}$ & 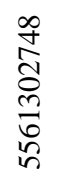 & 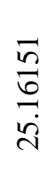 & $\frac{n}{8}$ & $\frac{8}{8}$ & 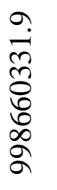 & 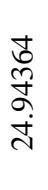 & 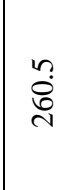 & $\begin{array}{l}8 \\
8 \\
8\end{array}$ & 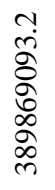 & $\begin{array}{l}\vec{n} \\
\stackrel{n}{ \pm} \\
\stackrel{i}{N}\end{array}$ & 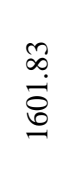 & $\begin{array}{l}8 \\
8 \\
8\end{array}$ & 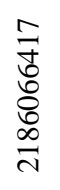 & 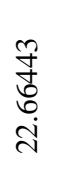 & 0 & $\frac{8}{8}$ & 0 \\
\hline Crude oil & 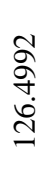 & 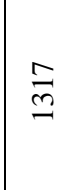 & 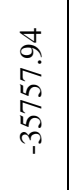 & 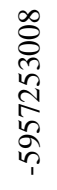 & $\underset{ }{\stackrel{\Xi}{n}}$ & $\frac{n}{7}$ & 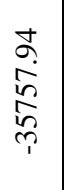 & 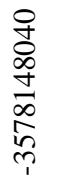 & 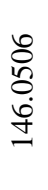 & $\begin{array}{l}n \\
\stackrel{8}{0} \\
\text { in }\end{array}$ & 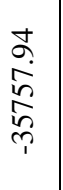 & 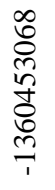 & $\begin{array}{l}\infty \\
\ddot{0} \\
\ddot{2}\end{array}$ & 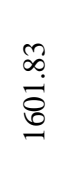 & 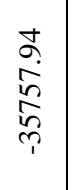 & 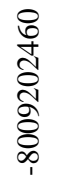 & 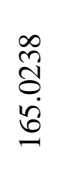 & 0 & 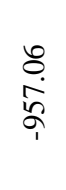 & 0 \\
\hline L.P.C (ID) & \multicolumn{4}{|c|}{5889088635} & \multicolumn{4}{|c|}{1167699250} & \multicolumn{4}{|c|}{447639200.9} & \multicolumn{4}{|c|}{3019576302} & \multicolumn{4}{|c|}{0} \\
\hline \multicolumn{14}{|c|}{ Total lost production cost (ID) } & \multicolumn{7}{|c|}{$10,524,003,388$} \\
\hline
\end{tabular}

Statistically, the best scheduled preventive maintenance cycle can be estimated based on the previous information and the following tables and equation.

Before that, the percentage of breakdowns for the five years of study (2012-2016) in Najaf Oil Refinery should be calculated as shown in the following tables (7)(8) :-

Table 7: Percentage of breakdowns in NOR for (20122016)[Researchers]

\begin{tabular}{|c|c|c|}
\hline No. & Year & No. of Preventive Shutdowns \\
\hline 1 & 2012 & 2 \\
\hline 2 & 2013 & 1 \\
\hline 3 & 2014 & 1 \\
\hline 4 & 2015 & 2 \\
\hline 5 & 2016 & 0 \\
\hline \multicolumn{2}{|c|}{ Total } & 6 \\
\hline
\end{tabular}

Table 8: Probability of failure in NOR [Researchers]

\begin{tabular}{|c|c|}
\hline Years & Probability of failure \\
\hline 1 & 0.34 \\
\hline 2 & 0.16 \\
\hline 3 & 0.16 \\
\hline 4 & 0.34 \\
\hline 5 & 0 \\
\hline
\end{tabular}

For calculating breakdowns rate:

Breakdowns rate $=1 * 0.34+2 * 0.16+3 * 0.16+4 * 0.34+5 * 0=2.5$

Now to calculate the breakdowns cost for the three production units in Najaf Oil Refinery:-

\section{Total lost Prouduction cost}

/breakdowns rate $\quad$........(5) [6]

$=10,524,003,388 / 2.5=4209601355.2 \mathrm{ID}$

Now to calculate the best scheduled preventive maintenance cycle based on statistical probability theory; it shows the expected number of stoppages if preventive maintenance was scheduled once a year, once in two years, once in three years and so on, as follows:

$$
\begin{gathered}
S_{n}=N \sum_{1}^{n} P_{n}+S_{n-1} * P_{1}+S_{n-2} * P_{2}+\cdots S_{1} \\
* P_{n-1} \cdots \cdots \cdots(6)[7]
\end{gathered}
$$

Where:-

$\mathrm{S}=$ number of cumulative expected failures during the period

$\mathrm{n}=$ expected number of stoppages

$\mathrm{N}=$ Number of production units

$\mathrm{P}=$ probability of stoppages

$S_{1}=N . P 1=3 * 0.34=1.02$

$$
\begin{gathered}
S_{2}=N(P 1+P 2)+S 1 P 1=3(0.34+0.16)+1.02 * 0.34 \\
=1.8468 \\
\begin{aligned}
S_{3}=N(P 1+P 2 & +P 3)+S 2 P 1+S 1 P 2 \\
& =3(0.34+0.16+0.16)+1.8468 * 0.34 \\
& +1.02 * 0.16=2.771112
\end{aligned}
\end{gathered}
$$

$$
\begin{aligned}
S_{4}=N(P 1+P 2 & +P 3+P 4)+S 3 P 1+S 2 P 2+S 1 P 3 \\
& =3(0.34+0.16+0.16+0.34) \\
& +2.771112 * 0.34+1.8468 * 0.16 \\
& +1.02 * 0.16=4.40086608 \\
S_{5}=N(P 1+P 2 & +P 3+P 4+P 5)+S 4 P 1+S 3 P 2 \\
& +S 2 P 3+S 1 P 4 \\
& =3(0.34+0.16+0.16+0.34+0) \\
& +4.40086608 * 0.34+2.771112 * 0.16 \\
& +1.8468 * 0.16+1.02 * 0.34 \\
& =5.5819603872
\end{aligned}
$$

It is possible now to calculate the best scheduled preventive maintenance period depending on the statistical probability theory as shown in the following table (9)

\section{Volume 6 Issue 7, July 2017 www.ijsr.net}




\section{International Journal of Science and Research (IJSR) \\ ISSN (Online): 2319-7064}

Index Copernicus Value (2015): 78.96 | Impact Factor (2015): 6.391

Table 9: Optimum scheduled preventive maintenance periodin NOR for years (2012-2016)[Researchers]

\begin{tabular}{|c|c|c|c|c|c|c|c|}
\hline Year & $\begin{array}{c}\text { Probability } \\
\text { of failure }\end{array}$ & $\begin{array}{c}\text { Cumulative } \\
\text { Probability of } \\
\text { failure }\end{array}$ & $\begin{array}{c}\text { Expected No. } \\
\text { of shutdowns }\end{array}$ & Cost of L.P.C & $\begin{array}{c}\text { Cost of preventive } \\
\text { maintenance }\end{array}$ & Total cost & Total cost per \\
year & & & & & \\
\hline 1 & 0.34 & 0.34 & 1.02 & 2146896691 & $183,845,550.28$ & $2,330,742,241.43$ & $2,330,742,241$ \\
\hline 2 & 0.16 & 0.5 & 1.8468 & 3887145891 & $183,845,550.28$ & $4,070,991,441.67$ & $2,035,495,721$ \\
\hline 3 & 0.16 & 0.66 & 2.771112 & 5832638415 & $183,845,550.28$ & $6,016,483,965.59$ & $2,005,494,655$ \\
\hline 4 & 0.34 & 1 & 4.40086608 & 9262945907 & $183,845,550.28$ & $9,446,791,457.49$ & $2,361,697,864$ \\
\hline 5 & 0 & 1 & 5.5819603872 & 11748914005 & $183,845,550.28$ & $11,932,759,555.59$ & $2,386,551,911$ \\
\hline
\end{tabular}

According to the above table, it is noted that the cost of Scheduled Preventive Maintenance Cost (SPMC) is down continuously to rise again after this decline. It is clear that the standard time for scheduled preventive maintenance (SPM) is located every (three years) which costing $(2,005,494,655)$ Iraqi Dinars, and will increase thereafter as noted in table (9).

So far, it is clear that preventive maintenance policy in the refinery per unit of production must be carried out once every (three years), ie, within the period in which maintenance costs are reduced minimally, in order to significantly minimize costs compared to previous costs when preventive maintenance operations were scheduled every five years, for example, as in the third production unit or once every two years as in the first production unit.

Finally, the Researchers asked the experts who working in the field of maintenance of Iraqi oil refineries on whether the results reached by the Researchers are logical and simulated reality, they accepted the results and they are representation of the reality of maintenance in Iraqi oil refineries.

\section{References}

[1] American Petroleum Institute (API) "Recommended Practice for Procedures for Inspections, Maintenance, Repair and Remanufacture of Hoisting Equipment" Seventh Edition, March 2002 (Reaffirmed: August 2012).

[2] EN 13306:2001, Maintenance Terminology. European Standard. CEN (European Committee for Standardization), Brussels, 2001.

[3] Wang, L., Chu, J. and Wu, J., "Selection of optimum maintenance strategies based on a fuzzy analytical hierarchy process", International Journal of Production Economics, Vol. 107, pp. 151-63, 2007.

[4] Gupta Dr. Tapen "Production and Operations Management”, Blogger, Mar., Haryana, India, 2009.

[5] AMCP 706-132, "Engineering Design Handbook: Maintenance Engineering Techniques", Department of Defense, Washington - Dc, 1975.

[6] HashimSaffaa Al Jazaeri "using operation research techniques in estimation of preuentive maintenance cycle" Al-taqani Journal, Vol.18, Issue 4, 2005 (Reaffirmed: August 2007).

[7] Ibrahim ZainabAllawi "A comparative study by computer to determine the optimum maintenance policy using a probabilistic model" Journal, The Iraqi Journal For Mechanical And Material Engineering Vol.15, No.4, 2015.
[8] Ali, Azlan-Shah, et al. "Factors affecting housing maintenance cost in Malaysia," Journal of facilities management, 2010. 